\title{
A GIS Based Morphometric Analysis of Watershed for Soil Erosion Planning
}

Santosh Wagh ( $\square$ sanganwagh@yahoo.co.in )

Sardar Vallabhbhai National Institute of Technology

Vivek Manekar

Sardar Vallabhbhai National Institute of Technology

\section{Research Article}

Keywords: Arc-GIS, Compound factor, Morphometric analysis, Soil erosion, Watershed

Posted Date: November 2nd, 2021

DOI: https://doi.org/10.21203/rs.3.rs-795826/v1

License: (c) (1) This work is licensed under a Creative Commons Attribution 4.0 International License. Read Full License 


\section{Abstract}

Soil erosion, if remain non attentive, will increase the sediment load of the river and also affecting the life of the hydraulic structures constructed across it. Hence, proper investigations related to the soil erosion is very much essential for watershed planners and designers. In the present study, morphometric analysis is carried out for basic, linear, areal, shape and landscape aspects using 28 morphometric parameters for Bhima river watershed to prioritize and categorized it based on its erosive potential. Total 48 toposheet of Survey of India of the scale 1:50,000 are used to delineate the watersheds for the preparation of base map containing information about drainage, contours, etc. so as to ensure accuracy and quality of the work. The All India Soil and Land Use Survey (AISLUS) codification is adopted for the study area. According to AISLUS, the study area falls under region 4, covered in 19 watersheds. Morphometric parameters in Arc-GIS software and compound factor method is employed to identify the sub-watersheds which are susceptible to soil erosion. Final Priority Ranking (FPR) based category map of watersheds is reported in this study by categorized it under five categories indicating \% area of each category (very high category: $15.94 \%$; high category: $23.50 \%$; medium category: $12.73 \%$; low category: $23.90 \%$; and very low category: $23.93 \%$ ). Based on the findings, this study is suggesting suitable sites soil conservation practices for reducing the sediment load in Bhima river watersheds as well as Ujjani reservoir, which will be useful to the concerning authorities for better management.

\section{Introduction}

Soil is one of the most important natural resource on the earth surface that supports life on the earth. Economic condition of the country also depends on the soil cover of the country (Naqvi et al. 2015). The development of land and water resources on a sustainable basis without deterioration and with constant increase in productivity is the mainstay of mankind ( $\mathrm{NIH}$. 2000). Soil erosion is the process of detachment and transportation of surface soil materials. Water is an important agent for soil erosion, land degradation and deterioration of soil fertility from topmost layer (Bhattacharaya et al. 2020). Worldwide, the total land area subjected to human induced soil degradation is estimated at about 2 billion hectares. The land area affected by soil degradation due to erosion is estimated at 1100 Mha by water erosion and 550 Mha by wind erosion (Nanda et al. 2015; Ganasri et al. 2016). In India, a land of $1,75,0000 \mathrm{Km}^{2}$ is prone to soil erosion out of its total land area of $3,28,0000 \mathrm{Km}^{2}$ (NIH. 2000). Thus, about $53 \%$ of the total land area of India is prone to erosion (Kadam et al. 2019).

A watershed is the total surface area of land from which a runoff resulting from rainfall is flowing through an outlet. The size of the watershed is dependent on the size of the interception of the stream or river and the drainage density and its distribution. The drainage network helps in delineation of watershed for a particular river system. Watershed and drainage basin can be subdivided into small sub-watersheds. In real situation, rainfall, runoff, soil, vegetation and topographic characteristics are found to vary greatly within the sub watersheds (Jain et al. 2000). Morphometric analysis is important to understand hydrological behavior of the watershed for development and management of natural resources (Malik et al. 2019). Therefore, identification of most important characteristics of a watershed is utmost important 
to understand its geomorphology (Arabameri et al. 2020). The elements like lithologic, geomorphic, morphometric, land use land cover (LULC) and soil which plays a significant role in sustainable watershed management (Balasubramanian et al. 2017; Bhattacharaya et al. 2020). A watershed therefore, need to be discretized into smaller homogenous units before making computations for soil loss. The watershed approach is now being employed in various development programs like soil and water conservation, command area development, erosion control in catchments of river valley projects, flood prone rivers, dry land/rain fed farming, reclamation of ravine lands, and control of shifting cultivation etc. These hydrologic units are equally important for development of water resources through major, medium and minor storage projects.

In order to conduct the detailed soil surveys on nation scale, the All India Soil and Land Use Survey (AISLUS) organization was established in 1958 under Ministry of Agriculture, Government of India. The AISLUS conducted soil survey of upper parts of catchment using Survey of India topographic maps and village cadastral maps. During early and mid-1960, aerial photographs were used to demarcate severely eroded and critical spots in different catchments (NIH. 2000). The AISLUS has published Watershed Atlas of India (1992) demarcating the major Water Resources Regions, Basins, Catchment, Sub catchment and Watersheds.

The resource development programs are applied generally on watershed basis and thus prioritization of watershed is essential for proper planning and management of natural resources for sustainable development (Kanth et al. 2010). Sediment yield is the key criteria for prioritizing the watershed. The major parameters, which are responsible for soil erosion in watershed are related with morphology, topography, soil type and vegetation characteristics prevalent in the area. The knowledge of basin hydrology is essential for proper management of water resources and flood hazard in a basin depending upon hydrological response of the upstream basin area (Pawar et al. 2014). Only quantification of soil erosion alone could not be useful in the management of watershed which is affected (Snehit et al. 2019). Rather, the morphological study will be helpful for watershed management against soil erosion. Morphometric analysis is an important aspect in geomorphology of a landform (Sahoo et al. 2019). Morphometric analysis of drainage basin gives essential information for the basin characterization. Various hydrological events can be investigated and accessed by the analysis of morphometric variables to study the impact on environmental dynamics of the basin (Subyani et al. 2010).

In the present study, prioritization of sub watershed study has been done for Bhima river watershed using morphometric parameters. The morphometric parameters of watersheds have been evaluated. The parameters may directly and/or inversely effect the soil erosion. The ranking based on soil erosion of all watersheds are evaluated. The ranks are then collectively added to give up a compound ranking (Javed et al. 2009; Snehit et al. 2019). The weighted compound factor method is employed to categorize the watersheds into five categories of soil erosion such as very high, high, medium, low and very low. Based on the findings, this study is recommending suitable site for check dams and other soil conservation practices. 


\subsection{Study Area}

In the present study, Bhima basin up to Ujjani reservoir is considered as study area. The Bhima basin is located in the western part of Maharashtra between $17^{0} 53^{\prime} \mathrm{N}$ to $19^{\circ} 24^{\prime} \mathrm{N}$ latitude and $73^{0} 20^{\prime} \mathrm{E}$ to $75^{\circ}$ $18^{\prime}$ E longitude. The basin covers a geographical area of $14,835 \mathrm{~km}^{2}$; comprising of 68 sub-basins. The basin is spread over the three districts of Maharashtra state namely Pune, Solapur and Ahmednagar. Total study area is comprising of $25 \%$ as hilly and/or highly dissected, $55 \%$ plateau and the remaining is plain area. Associated hydrological feature of the study area is that about $25 \%$ of the Bhima basin, lying in the western zone, falls in good rainfall region. Remaining $75 \%$ is rainfall deficit region; having annual rainfall less than $700 \mathrm{~mm}$. In the Parner-Shirur region, rainfall is normally less than $600 \mathrm{~mm}$. Of the total rainfall, $85 \%$ comes from South-West monsoon during June-September, $11 \%$ from North-East monsoon during September-December, and about $4 \%$ after December. About $89 \%$ of the basin is classified as drought-prone.

During the journey of Bhima, many small rivers are joining to it. The main tributaries of the river are: Ghod and Mula-Mutha rivers. Mula rises in Mulshi taluka, and Mutha in Velhe. river Ghod and its tributaries Kukadi and Meena also rise in the Sahyadri Ghats. The places of origins of the tributaries of Bhima fall in comparatively heavy rainfall region. Length of Bhima up to Ujjani is $275 \mathrm{~km}$. The Bhima basin is mainly covered by Deccan trap lava flows. The Deccan trap is vast pile of volcanic lava flows laying one over the other and is more or less uniform in chemical composition. It includes the other volcanic products such as tuff, breccia, ash beds etc. The Deccan Trap lava flows have been considered as horizontal beds. But some of the section indicates that many of the flows have dips ranging between 5 to 40 meters per kilometer. The slopes in the northern part of the Bhima basin catchments are moderate, whereas in the southern part slopes ranges from moderately steep to steep (Wagh et al. 2021). Nearly level to gentle slopes are seen in the central part of the Bhima basin. Figure 1 shows the location map of the study area.

\section{Methodology}

\subsection{Data Sources}

\subsubsection{The All India Soil and Land Use Survey (AISLUS) Data}

The All India Soil and Land Use Survey (AISLUS) organization has developed a system for delineating and codifying the catchment areas into smaller hydrologic units, i.e., watersheds following the four-stage delineation. The entire country is divided into six major water resources region. There are total 35 basins, 112 catchments, 500 sub-catchments and 3237 watersheds following a five stage delineation approach (NIH. 2000). The study area i.e. Bhima basin falls under region 4, basin 4D, catchment 4D7 and sub catchment 4D7F, 4D7G and 4D7H. The codification of sub watersheds is adopted as per the All India Soil and Land Use Survey (AISLUS). The watersheds are coded as 4D7F1 to 4D7F5, 4D7G1 to 4D7G7 and $4 \mathrm{D} 7 \mathrm{H} 1$ to $4 \mathrm{D} 7 \mathrm{H} 7$. The study area is covered under 19 watersheds. 


\subsubsection{Survey of India Toposheet Data}

Toposheet by Survey of India, scale 1:50,000, are used to delineate the study area. Toposheet are used not only to delineate the watersheds and micro-watersheds but also for the preparation of base map containing information about drainage, contours etc. In this process total numbers of 48 toposheet data is used. The toposheet 47E7-E8, 47E11-E12, 47E15-16, 47F5-F16, 47I3-4, 47I7-8, 47I11-12, 47I15-16, 47J1$16,47 N 1-4,47 N 7-8$ are used for the study area. The methodology includes the scanning of toposheet in TIFF format, importing the scanned toposheet in .img format, geo-referencing of masked, mosaicked toposheet and resampled into Universal Transverse Mercator (UTM) projection WGS 1984, zone 43 North. ERDAS IMAGINE software 2014 is used for delineating the study area from the toposheet. Contours at 20 $\mathrm{m}$ intervals for plain area and at $100 \mathrm{~m}$ intervals at steep sloping area and dense forest area is digitized from mosaic of resampled toposheet. A $20 \mathrm{~m}$ spatial resolution DEM is generated using ArcGIS software version 10.3

\subsection{Morphometric Analysis}

The morphometric study of the Bhima basin helps in the estimation of dynamic characteristics of a river basin. All the properties of morphometric analysis help to know the character of the stream network as well as the basin. The morphometric analysis could be used effectively for watershed prioritization and categorization even without a soil map (Ratnam et al. 2005; Gajbhiye et al. 2014). The morphometric analysis is carried out for basic, linear, areal, shape and landscape aspects using the mathematical expressions. The present study considered 28 morphometric parameters which are estimated by using the relationships as mentioned below in Table 1.

The ranking of 19 watersheds are done as initial priority ranking (IPR). The correlation between the parameters are examined. These correlated values are then used for estimating weighted sum approach, which is further used for deciding the final priority ranking (FPR).

\subsection{Compound Factor Method}

This method is based on the principles of knowledge driven modelling. The modelling converts the qualitative understanding of phenomenon by scientific knowledge into a quantitative estimation (Snehit et al. 2019). In this method rank is assigned to every morphometric parameter according to their value. The average of ranks of all the parameters is designed as compound value. The mean value of assigned ranks for a watershed represents its relative priority compared to others (Hembram et al. 2018). This represents the collective impact of all the parameters (Javed et al. 2009). This model is as shown in Eq. 1. (Hembram et al. 2018).

$$
C F=\frac{1}{n} \sum_{i=1}^{n} R i
$$

Where, $\mathrm{CF}=$ Compound value; $\mathrm{Ri}=$ Rank of options; and $\mathrm{n}=$ Number of parameters 
Close observation of Eq. 1 implies that there is no term indicating correlation between the morphometric parameters reflected in this model. This is the limitations of this model. The flow chart of the methodology used in this study is shown below in Fig. 2 .

\section{Results And Discussion}

The obtained results of this study are reported under three sections. The first section deals with the basic morphometric parameters which are derived from DEM using Arc-GIS tool. The second section deals with the linear, areal, slope and landscape parameters. The third section deals with the prioritization of watershed on the basis of linear, areal, slope and landscape parameters.

\subsection{Basic Morphometric Parameters}

The basic parameters are very much important for evaluating linear, areal, slope and landscape indices (Hembram et al. 2018). The information about the basin area (A), basin perimeter (P), basin length $\left(L_{b}\right)$, maximum height $\left(\mathrm{H}_{\text {max }}\right)$, minimum height $\left(\mathrm{H}_{\text {min }}\right)$ and mean height $\left(\mathrm{H}_{\text {mean }}\right)$ of the basin are derived from delineated watershed. The parameters are estimated using relations mentioned in Table 1 and obtained results are reported below in Table 2.

The watershed 4D7G7 has the biggest area while the watershed $4 \mathrm{D} 7 \mathrm{H} 5$ is smallest one. The elevation of $4 \mathrm{D} 7 \mathrm{H} 7$ watershed is the highest while the elevation of watershed 4D7F1 is lowest one. Basin length is the longest dimension of the basin parallel to the principal drainage line. It can be observed from Table 2 that watershed 4D7G7 have greater basin length whereas the watershed 4D7G1 have least basin length. Basin length is directly related with the erodibility. Higher the basin length, high is the erodibility, and vice versa.

\subsection{Linear Morphometric Parameters}

Linear parameters like stream order $(N)$, number of streams $\left(N_{s}\right)$, stream length $\left(L_{s}\right)$, bifurcation ratio $\left(R_{b}\right)$ and mean bifurcation ratio $\left(R_{b m}\right)$ of watersheds are measured in GIS environment. The parameters are estimated as per the estimating relations given in Table 1 and obtained results of the parameters are reported below in Table 3.

\subsubsection{Stream Order $(\mathrm{N})$}

Stream order is the first step of morphometric analysis. Stream order is delineated in each watershed of the Bhima basin. It is delineated according to the Strahler's stream ordering rule (Strahler et al. 1957). According to Strahler's system of stream ordering, fingertip tributaries are taken as $1 \mathrm{st}$ order stream. Two 1 st order streams combine to form a 2nd order stream. Two 2 nd order streams combine to form a 3rd order stream and so on. It is found that stream order increases, number of streams decreases.

\subsubsection{Stream Number $\left(\mathbf{N}_{\mathrm{s}}\right)$}


The total stream segments present in a particular order of stream is called as stream number. The total stream number in a particular stream order and in each watershed of the Bhima basin is estimated by using ArcGIS 10.3. Watershed 4D7G4 have more streams while the watershed 4D7H2 have less streams.

\subsubsection{Stream Length $\left(L_{s}\right)$}

The total length of stream order in a particular order of stream is called as stream length. ArcGIS is used to evaluate the total stream length in a particular stream order and in each watershed of the Bhima basin. Generally, stream length decreases with increase in stream order. Longer stream length indicates flatter slope and shorter stream length indicates steep slope and finer texture. Lengthwise the watershed 4D7G7 have more stream lengths while the watershed 4D7H5 have less stream lengths. The results are tabulated below in Table 3.

\subsubsection{Bifurcation Ratio $\left(R_{b}\right)$}

Bifurcation ratio is derived as the ratio of the stream numbers in a particular order and the stream numbers in the next higher order. It is denoted by $\mathrm{R}_{\mathrm{b}}$. It shows the form of drainage basin. It is considered as the index of relief. It is a dimensionless property. Lower $\mathrm{R}_{\mathrm{b}}$ values are the characteristics of structurally less distributed watersheds without any distortion in drainage pattern (Meshram et al. 2015). Higher bifurcation ratio implies high runoff and low permeability of the drainage basin. From Table 3 values of bifurcation ratio ranges from 0.16 to 5.46 .

\subsubsection{Mean Bifurcation ratio $\left(R_{b m}\right)$}

Mean bifurcation ratio is calculated by the arithmetic mean of the bifurcation ratio of all the streams. It is denoted by $\mathrm{R}_{\mathrm{bm}}$. Higher the $\mathrm{R}_{\mathrm{bm}}$ high is the erodibility, and vice versa. Values of mean bifurcation ratio ranges from 1.56 to 2.77 . The obtained result is tabulated as per watershed of the basin in Table 4 . The categorization of watersheds as per mean bifurcation ratio is shown below in Fig. 3 .

In this study, stream length and stream numbers are determined using GIS tool. The drainage network pattern of Bhima basin indicates that it is a 6th order watershed consisting steams of various order. The detail of all the steam orders, stream numbers and bifurcation ratio of 19 watersheds is given in Table 3. It reveals that there are 17417 streams of 1st order, 8053 of 2nd order, 4114 of 3rd order, 3055 of 4 th order, 2237 of 5th order and 304 of 6th order. It is also seen from Table 3 that highest stream lengths are found in watershed 4D7G7 (1598) and the lowest stream lengths are found in 4D7H5 (396). The total length of all streams for the watersheds is $15731 \mathrm{Km}$.

In the study area, it is seen from Fig. 3 that the watershed 4D7F5 has the highest value of mean bifurcation ratio, indicates a high structural complexity and low permeability of terrain. More the value of $\mathrm{R}_{\mathrm{bm}}$ the more will be the soil erosion (Malik et al. 2019). Low value of $\mathrm{R}_{\mathrm{bm}}$ means less distortion due to drainage (Hembram et al. 2018). It is observed from Fig. 3 that, eleven watersheds are of very low mean bifurcation ratio, three watersheds are of low, three watersheds are of medium, one watershed is high and one watershed is very high category. 


\subsection{Areal Morphometric Parameters}

The parameters drainage density $\left(D_{d}\right)$, stream frequency $\left(F_{s}\right)$, texture ratio $\left(R_{t}\right)$, length of overland flow $\left(\mathrm{L}_{\mathrm{of}}\right)$ and constant of channel maintenance $\left(\mathrm{C}_{\mathrm{cm}}\right)$ have direct relation with the erodibility (Kadam et al. 2019). The categorization of watersheds as per areal morphometric parameters are shown in Fig. 4.

\subsubsection{Drainage Density $\left(D_{d}\right)$}

Drainage density is the ratio of total channel segment lengths cumulated for all orders within a basin to the basin area. The drainage density is expressed in terms of $\mathrm{Km} / \mathrm{Km}^{2}$. Drainage density depends on permeability of sub surface elements, type of vegetation and terrain relief. Lower $D_{d}$ indicates highly permeable subsurface, good type of vegetation, low roughness, whereas opposite condition produces high $D_{d}$. (Arabameri et al. 2020). Higher drainage density represents a relatively higher number of streams per unit area and thus a rapid storm response. Higher drainage density represents conditions favorable for higher erosion from the catchment. From Table 4, values of drainage density range from 0.94 to 1.20 $\mathrm{Km} / \mathrm{Km}^{2}$, indicating low drainage density. The low drainage density in all the watersheds suggests that the Bhima basin is highly permeable subsoil and coarse drainage texture.

\subsubsection{Stream Frequency $\left(F_{s}\right)$}

Stream frequency depends upon the rate of recurrence of the stream viz., frequency and area of the sub watersheds. The morphometric parameter is direct relationship with the erodibility. higher the stream frequency, higher will be erodibility and vice versa. Stream frequency values indicate positive correlation with the drainage density for all watersheds indicating increase in stream population with respect to increase in drainage density. From Table 4, it can be observed that $4 D 7 G 4\left(F_{s}=3.58\right)$ have maximum stream frequency whereas 4D7F4 $\left(F_{s}=1.75\right)$ have minimum stream frequency.

\subsubsection{Texture Ratio $\left(R_{t}\right)$}

Texture ratio is the crucial consideration in drainage analysis depending on the relief aspect of the terrain. From Table 4, it can be observed that the maximum texture ratio is with respect to 4D7G4 $\left(R_{t}=27.40\right)$ refers to high sensitivity to erosion and minimum texture ratio is with respect to $4 D 7 H 5\left(R_{t}=6.54\right)$ refers to low sensitivity to erosion.

\subsubsection{Length of Overland Flow $\left(\mathrm{L}_{\mathrm{of}}\right)$}

The overland flow and surface runoff are different terms; overland flow refers to that flow of precipitated water which moves over the land surface leading to the stream channel, while the channel flow reaching outlet of the watershed is termed as surface runoff. From Table 4, it can be observed that the maximum length of overland flow is with respect to $4 \mathrm{DFF} 1$ and $4 \mathrm{D} 7 \mathrm{~F} 3\left(\mathrm{~L}_{\mathrm{of}}=0.53 \mathrm{Km}\right)$ refers to high sensitivity to erosion and minimum length of overland flow is with respect to $4 D 7 G 2$ and $4 D 7 H 6\left(L_{\text {of }}=0.42 \mathrm{Km}\right)$ refers to low sensitivity to erosion. 


\subsubsection{Constant of Channel Maintenance $\left(\mathrm{C}_{\mathrm{cm}}\right)$}

Constant of channel maintenance have direct relationship to erodibility. Higher $\mathrm{C}_{\mathrm{cm}}$ value indicates the high infiltration and low runoff. From Table 4, maximum $C_{c m}$ corresponds to 4D7F3 $\left(C_{c m}=1.06\right.$ Sq. $\mathrm{km} / \mathrm{km})$ and minimum $\mathrm{C}_{\mathrm{cm}}$ corresponds to $4 \mathrm{D} 7 \mathrm{H} 6\left(\mathrm{C}_{\mathrm{cm}}=0.83 \mathrm{Sq} \cdot \mathrm{km} / \mathrm{km}\right)$.

Higher values of drainage density, stream frequency, texture ratio is seen in western part of the study area (Fig. 4). It indicates that such watersheds are underlain by impermeable rocks, which are responsible for high surface run off. The study of length of overland flow shows that it is a dominant hydrological parameter which has a great effect on shape of hydrograph. In the study area, average length of overland flow is estimated as $0.47 \mathrm{Km}$ (Table 4) which shows high surface runoff leading to high soil erosion. The relationship between constant of channel maintenance and soil erosion is analogous to the relationship between drainage density and stream frequency (Arabameri et al. 2020). The determination of areal parameters is found to be important for the estimation of soil erosion.

\subsection{Shape Morphometric Parameters}

The shape parameters form factor $\left(F_{f}\right)$, elongation ration $\left(R_{e}\right)$, compactness coefficient $\left(C_{c}\right)$ and circulatory ratio $\left(R_{c}\right)$ have inverse relation with the sediment yield per unit area. The categorization of watersheds as per shape parameters are shown in Fig. 5.

\subsubsection{Form Factor $\left(F_{f}\right)$}

Form factor is the dimensionless ratio of basin area to the square of basin length. It indicates the shape of the basin. Lesser $F_{f}$ value indicates highly elongated nature of the basin and higher $F_{f}$ value indicates highly circular nature of the basin. Watershed with high $\mathrm{F}_{\mathrm{f}}$ has high peak flows of shorter duration, whereas watershed with low $\mathrm{F}_{f}$ has lower peak flows for longer duration. From Table 4, maximum $F_{f}$ occurs in 4D7G1 $\left(F_{f}=0.62\right)$ with least priority refers to circular shape and minimum $F_{f}$ occurs in 4D7H5 $\left(F_{f}=0.10\right)$ with high priority refers to elongated shape of the basin.

\subsubsection{Elongation Ratio $\left(R_{e}\right)$}

Elongation ratio is defined as the ratio of diameter of a circle having the same area as that of the basin to the maximum length of the basin. Elongation ratio varies from 0 to 1 . Higher value of $R_{e}$ indicates the circular shape of the watershed and lower value indicates the elongated shape of the watershed. From Table 4 maximum $\mathrm{R}_{\mathrm{e}}$ value occurs in $4 \mathrm{D} 7 \mathrm{G} 1\left(\mathrm{R}_{\mathrm{e}}=0.89\right)$ with least priority and minimum $R_{e}$ value occurs in $4 \mathrm{D} 7 \mathrm{H} 5\left(\mathrm{R}_{\mathrm{e}}=0.36\right)$ with high priority.

\subsubsection{Compactness Coefficient $\left(\mathrm{C}_{\mathrm{c}}\right)$}

It is calculated as ratio of basin perimeter to the circle perimeter of same area of watershed. It develops the relationship between actual hydrologic basin and circular basin having same area. It is directly 
proportional to infiltration. From Table 4, maximum $\mathrm{C}_{\mathrm{c}}$ value occurs in $4 \mathrm{D} 7 \mathrm{H} 5\left(\mathrm{C}_{\mathrm{c}}=1.98\right)$ and minimum $C_{c}$ value occurs in $4 \mathrm{D} 7 \mathrm{G} 1\left(\mathrm{C}_{\mathrm{c}}=1.23\right)$. The values of $\mathrm{C}_{\mathrm{c}}$ vary from 1.23 to 1.98 .

\subsubsection{Circulatory Ratio $\left(R_{c}\right)$}

Circulatory ratio is calculated as ratio of area of basin to the area of circle having equivalent circumference to the perimeter of the basin. Generally, the value of $R_{c}$ varies from 0 to 1 . Lower value indicates elongated nature whereas higher value indicates circular nature of the basin. (Pawar et.al. 2014). From Table 4, the value of $R_{c}$ ranges from 0.26 to 0.66 indicates that all the watersheds are elongated in shape. Lower $R_{c}$ value have high priority whereas higher $R_{c}$ value have low priority. Maximum $R_{c}$ value occurs in $4 D 7 G 1\left(R_{c}=0.66\right)$ and minimum $R_{c}$ value occurs in $4 D 7 H 5\left(R_{c}=0.26\right)$.

In the study area values of form factor varies from 0.10 to 0.62 . Values greater than 0.78 indicated the circular basin (Javarayigowda et al. 2018), while smaller values suggest the elongated basin. The average form factor of Bhima basin is estimated as 0.24 (Table 4), indicating the basin is more elongated and susceptible to more soil erosion. The estimation of elongation ratio for watersheds in Bhima basin are observed in the range of 0.36 to 0.89 (Table 4). The watershed 4D7G1 $\left(R_{e}=0.89\right)$ has circular shape with sharp peak flood discharge, whereas the remaining watersheds are marked as elongated shape with peak flows for longer duration. More the value of compactness coefficient, less is the soil erosion and vice versa. $C_{c}$ value $>1$ represents that the shape of watershed is deviated from circular shape. From Table 4 it is observed that Watersheds $4 \mathrm{D} 7 \mathrm{H} 5\left(\mathrm{C}_{\mathrm{C}}=1.98\right), 4 \mathrm{D} 7 \mathrm{~F} 1\left(\mathrm{C}_{\mathrm{c}}=1.93\right)$ and $4 \mathrm{D} 7 \mathrm{H} 1\left(\mathrm{C}_{\mathrm{C}}=1.83\right)$ indicating higher infiltration capacity and hence less susceptible to soil erosion as compared with the remaining watersheds in study area. The average circulatory ratio of Bhima basin is 0.42 . This shows that the basin is elongated and permeable to geologic material. Watershed $4 D 7 H 5\left(R_{c}=0.26\right)$ (Table 4) shows the lowest $R_{c}$ value which in turn reflect rapid discharge and more soil erosion. Watershed 4D7G1 $\left(R_{c}=0.66\right)$ (Table 4$)$ shows the highest $R_{c}$ value reflects low discharge from watershed and less soil erosion.

\subsection{Landscape Morphometric Parameters}

Landscape parameters of the basin are relating to the elevation features to analyze terrain characteristics. These parameters have direct relation with the soil erosion. The parameters basin relief $(R)$, ruggedness number $\left(R_{N}\right)$, relief ratio $\left(R_{r}\right)$, relative relief $\left(R_{r f}\right)$ relief peakedness $\left(R_{p k}\right)$, hypsometric integral $\left(H_{1}\right)$, slope $(G)$ and ruggedness index $\left(R_{G}\right)$ are grouped under landscape parameters. The categorization of watersheds as per landscape parameters are shown below in Fig. 6 .

\subsubsection{Basin Relief (R)}

Basin relief is the difference between the elevation of highest point and lowest point of the watershed. Higher basin relief indicates low infiltration and high runoff. From Table 4, 4D7F1 ( $R=129 \mathrm{~m}$ ) has the 
least basin relief and 4D7H7 $(R=547 \mathrm{~m})$ has the highest basin relief. Higher basin relief indicates low infiltration and high run off, hence more erosion.

\subsubsection{Ruggedness Number $\left(R_{N}\right)$}

Ruggedness number is a dimensionless number, which can be obtained by product of basin relief and drainage density of same unit. From Table 4 , maximum value of ruggedness number $\left(R_{N}=0.61\right)$ occurs in $4 D 7 H 7$ watershed and minimum value of ruggedness number $\left(R_{N}=0.12\right)$ occurs in 4D7F1 watershed. The value of $R_{N}$ varies from 0.12 to 0.61 . $R_{N}$ values indicate the structural complexity of the watersheds in association with relief and drainage density. Higher values implies that the area is more susceptible to erosion.

\subsubsection{Relief Ratio $\left(R_{r}\right)$}

Relief ratio is obtained by dividing the basin relief and basin length. Relative relief is directly related with the slope, also affects the hydrological process (Arabameri et al. 2020). The relief ratio is an indicator of erodibility in watershed which measures the steepness of watershed. High value of $R_{r}$ represents the hilly region and vice versa. From Table 4, maximum value occurs in $4 D 7 H 7\left(R_{r}=10.94\right)$ with high priority and minimum value occurs in 4D7F1 $\left(R_{r}=1.64\right)$ with least priority. Thus it can be said that $R_{r}$ has a direct relation with the erodibility. The values of $R_{r}$ varies from 1.64 to 10.94 .

\subsubsection{Relative Relief $\left(R_{\mathrm{rf}}\right)$}

It is an important morphometric parameter used for overall assessment of morphometric characteristic of any topography (Javarayigowda et al. 2018). Relative relief is given by the ratio of basin relief to the perimeter of the watershed. From the Table 4, watershed $4 D 7 H 7$ has the maximum $R_{r f}\left(R_{r f}=4.53\right)$ with high priority and 4D7F1 has the minimum $R_{r f}\left(R_{r f}=0.71\right)$ with least priority.

\subsubsection{Relief Peakedness $\left(R_{\mathrm{pk}}\right)$}

Relief peakedness is given by the ratio of mean elevation to maximum elevation of the watershed (Khawaja et al. 2008). From the Table 4, 4D7F1 has the maximum $R_{p k}\left(R_{p k}=0.88\right)$ and 4D7G4 has the minimum $R_{p k}\left(R_{p k}=0.62\right)$. The values of $R_{p k}$ varies from 0.62 to 0.88 . Relative peakedness has direct relation with erosion.

\subsubsection{Hypsometric Integral $\left(\mathrm{H}_{\mathrm{l}}\right)$}

It is used to determine the geomorphic stages of development of watersheds and express how the mass is distributed within a watershed from bottom to top (Meshram et al. 2015). It is given by $\left(\mathrm{H}_{\text {mean }}-\mathrm{H}_{\min }\right) /$ $\left(H_{\max }-H_{\text {min }}\right)$ (Yang et al. 2014). From the Table 4, 4D7F1 has the maximum $H_{l}\left(H_{1}=0.43\right)$ and 4D7G2 has the minimum $H_{1}\left(H_{1}=0.15\right)$. Hypsometric integral has direct relation with erosion.

\subsubsection{Slope (G)}


Slope is the ratio of mean elevation of the watershed to the square root of the watershed area. Steep slopes are observed at the periphery of the watershed. Slope plays key role in runoff and stream discharge (Kadam et al. 2019). Slope are directly proportional to land and water degradation where higher value of slope gives greater sediment yield per unit area. From the Table 4, 4D7H5 has the maximum slope $(G=37.43)$ with high priority and $4 D 7 G 7$ has the minimum slope $(G=17.38)$ with least priority. The slope value varies from 17.38 to 37.43 .

\subsubsection{Ruggedness Index $\left(R_{G}\right)$}

Ruggedness index is given by $R^{\star} A^{-0.5}$ (Yang et al. 2014). From the Table 4, 4D7H5 has the maximum $R_{G}$ $\left(R_{G}=25.53\right)$ and $4 D 7 F 1$ has the minimum $R_{G}\left(R_{G}=4.85\right)$. From Table $4,4 D 7 H 5$ has the maximum ruggedness index with high priority and 4D7F1 has the minimum ruggedness index with least priority. The ruggedness index has direct relation with erosion. The ruggedness index value varies from 4.85 to 25.53.

Figure 6 Landscape parameters of the study area: a. ruggedness number, b. relief ratio, c. relative relief, $\mathbf{d}$. relief peakedness, e. hypsometric integral, f. slope, g. ruggedness index

Landscape parameters are the topographic parameters and derived from DEM. Higher values relate with more erosion and lower values less erosion except relief peakdness, which is inversely proportional to erosion. From Fig. 6 it is stated that more soil erosion is seen in uppermost part of the study area, where more values of elevation are estimated from DEM.

\subsection{Priority Ranking}

To determine the importance and contribution of each morphometric parameter to determine soil erosion potential priority ranking of watersheds are required. In prioritization process, hierarchy of different watersheds according to priority ranks are then taken up for soil conservation and treatment (Kadam et al. 2019).

\subsection{Initial Priority Ranking (IPR)}

Initial priority ranking is done on the basis of morphometric characteristics which are estimated according to linear, areal, shape and landscape parameters. The parameters which are directly relate with the erosion are, for them largest value given as highest rank. Similarly, the parameters which are inversely related with the soil erosion, for these parameters lowest value given as highest value. If two watersheds have same value, then equal rank is assigned to such watersheds. The sum of all the parameters for each watershed is calculated. The compound factor of every watershed is calculated as dividing the sum by number of parameters. Finally, initial priority ranking according to the calculated compound factor value. Table 5 shows the initial priority ranking of 19 watersheds estimated for 17 morphometric parameters.

\subsection{Weighted Compound Factor Method}


Different watersheds behave differently according to their characteristics, It is consider that all the parameters cannot be of equal importance in the estimation of erosion and prioritization of watersheds (Aher et al. 2014). Weighted sum approach is a rigorous statistical method, which is coupled with geospatial technologies to identify critical parameters which should be considered in the final combination for analysis (Rahmati et al. 2019). In this method the cross-correlation matrix of these parameters have been developed as shown in Table 6 . These results are used in calculating weighted compound factor for watersheds. The results obtained from initial priority ranking is multiplied with the weights obtained using cross correlation analysis to give compound factor for final prioritization of watersheds (Malik et al. 2019).

The weighted compound factor for watershed is calculated as follows:

Weighted compound factor $=\left[\left(0.038 \times\right.\right.$ IPR of $\left.R_{b m}\right)+\left(-0.014 \times\right.$ IPR of $\left.D_{d}\right)+\left(0.128 \times\right.$ IPR of $\left.F_{s}\right)+(0.065 \times$ IPR of $\left.R_{t}\right)+\left(0.003 \times\right.$ IPR of $\left.L_{\text {of }}\right)+\left(0.003 \times\right.$ IPR of $\left.C_{c m}\right)+\left(0.061 \times\right.$ IPR of $\left.F_{f}\right)+\left(0.67 \times\right.$ IPR of $\left.R_{e}\right)+(-0.009 x$ IPR of $\left.C_{c}\right)+\left(0.012 \times\right.$ IPR of $\left.R_{c}\right)+\left(0.119 \times\right.$ IPR of $\left.R_{N}\right)+\left(0.188 \times\right.$ IPR of $\left.R_{r}\right)+\left(0.149 \times\right.$ IPR of $\left.R_{r f}\right)+(-0.080 \times$ IPR of $\left.R_{p k}\right)+\left(0.011 \times\right.$ IPR of $\left.H_{1}\right)+(0.113 \times$ IPR of $G)+\left(0.144 \times\right.$ IPR of $\left.\left.R_{G}\right)\right]$ (Malik et al. 2019). (2)

\subsection{Final Priority Ranking (FPR)}

The compound factor estimated by using weighted sum approach is used for final priority ranking of watersheds. Addition of all weighted compound factor values of parameters for 19 watersheds is taken. Thus, the soil and water conservation measures can be applied according to the priority ranking. Final priority ranking is made in such a way that the lowest value of weighted compound factor value is assigned as 1st rank, the next lower value is assigned rank 2nd and so on. Estimation of final priority ranking is tabulated below in Table 8 .

It is observed from Table 6 that the combination length of overland flow $\left(\mathrm{L}_{\mathrm{of}}\right)$ with constant of channel maintenance $\left(C_{c m}\right)$, form factor $\left(F_{f}\right)$ with elongation ratio $\left(R_{e}\right)$, relative relief $\left(R_{r f}\right)$ with ruggedness number $\left(R_{N}\right)$ and ruggedness index $\left(R_{G}\right)$, has significant positive correlation, while the combination of drainage density $\left(D_{d}\right)$ with length of overland flow $\left(L_{o f}\right)$ and constant of channel maintenance $\left(C_{c m}\right)$, compactness coefficient $\left(C_{c}\right)$ with circulatory ratio $\left(R_{c}\right)$, ruggedness number $\left(R_{N}\right)$ with relief peakedness $\left(R_{p k}\right)$ has significant negative correlation. Using Eq. 2 the weighted compound factor for 19 watersheds for 17 morphometric parameters are calculated and tabulated in Table 7, which is used for final priority ranking of watersheds.

As observed from Table 8 that highest priority rank 19 is assigned to watershed $4 \mathrm{D} 7 \mathrm{H} 7$ followed by 4D7H5, 4D7H4, 4D7G3, 4D7G4, 4D7G7, 4D7G6, 4D7H6, 4D7G5, 4D7F5, 4D7G2, 4D7H3, 4D7H2, 4D7H1, 4D7G1, 4D7F2, 4D7F1, 4D7F4, 4D7F3. Figure 7 shows the final priority ranking map of Bhima basin of 19 watersheds under study. The 19 watersheds are classified in five priority categories (Aher et al. 2014; Malik et al. 2019) such as (i) very low (4.59 to 7.12), low (7.12 to 9.65), medium (9.65 to 12.19), high (12.19 to 14.72) and very high (14.72 to 17.26) as given in Table 9. It is observed from Table 9 that four watersheds (4D7G3, 4D7H4,4D7H5 and 4D7H7) are under very high category, three watersheds (4D7G4, 
4D7G6 and 4D7G7) are under high category, two watersheds (4D7G5 and 4D7H6) are under medium category, five watersheds (4D7F5, 4D7G2, 4D7H1, 4D7H2 and 4D7H3) are under low category, five watersheds (4D7F1, 4D7F2, 4D7F3,4D7F4 and 4D7G1) are under very low category. Using this information final watershed priority category map is prepared shown in Fig. 7. It is revealed from Fig. 7 that watershed area under very high category is 15.94 percent, high category is 23.50 percent, medium category is 12.73 percent, low category is 23.90 percent and very low category is 23.93 percent.

Check dam structure is proposed to intercept water from catchment and store it for irrigation and other use. Storage dams can be constructed on 3rd order of streams and check dams are constructed at $2 \mathrm{Km}$ down stream of storage tanks on 4th or 5th order of streams (Durbude et al. 2001). Lift irrigation scheme is proposed on check dams on 5th order of streams to have irrigation of farms in command area. An earthen bund should be constructed across gentle slope in valley portion to collect water for farmland and reduce soil erosion. Where ever possible plantation of trees on barren land and forest land should be done to increase the canopy, vegetation covers to reduce the sediment yield directly coming into the reservoirs in study area, and also to enhance the life of reservoirs.

\section{Conclusions}

The prioritization of watershed is most critical activity for execution. The morphometric analysis is carried out for basic, linear, areal, shape and landscape aspects using GIS tool. The application of Remote Sensing (RS) technique in conjunction with Geographic Information System technique is found to be more efficient for morphometric studies and prioritization of watersheds. Use of Toposheet data is recommended to delineate the watersheds, micro-watersheds and for the preparation of base map to enhance the accuracy and quality of the prioritization work. The prioritization of 19 watersheds is done using weighted compound factor approach in conjunction with statistical correlation analysis to attain better accuracy. The result shows that watersheds $4 \mathrm{D} 7 \mathrm{G} 3,4 \mathrm{D} 7 \mathrm{H} 4,4 \mathrm{D} 7 \mathrm{H} 5$ and $4 \mathrm{D} 7 \mathrm{H} 7$ are prone to more soil erosion followed by 4D7G4, 4D7G6 and 4D7G7watersheds. It is therefore require to implement soil erosion control measures in these watersheds to prevent further deterioration of soil. This information is useful to government agencies, local authorities for implementations of watershed management techniques such as soil conversion measures in the study area. This information is also useful to water resources department for implementing catchment area treatments by providing check dams and vegetation cover for reducing sediment yield in the reservoirs in the study area.

\section{Declarations}

All authors certify that they have no affiliations with or involvement in any organization or entity with any financial interest or non-financial interest in the subject matter or materials discussed in this manuscript.

\section{References}


1. Aher PD, Adinarayana J, Gorantiwar SD (2014) Quantification of morphometric characterization and prioritization for management planning in semi-arid tropics of India: a remote sensing and GIS approach. Journal of Hydrology 511; 850-860. http://dx.doi.org/10.1016/j.jhydrol.2014.02.028

2. AISLUS (1958) The All India Soil and Land Use Survey Organization. Ministry of Agriculture, Government of India.

3. Arabameri A, Tiefenbacher JP, Blaschke T, Pradhan, B, Tien BD (2020) Morphometric analysis for soil erosion susceptibility mapping using novel gis-based ensemble model. Remote Sensing, 12(5); 874

4. Balasubramanian A, Duraisamy K, Thirumalaisamy S, Krishnaraj, S, Yatheendradasan, RK (2017) Prioritization of subwatersheds based on quantitative morphometric analysis in lower Bhavani basin, Tamil Nadu, India using DEM and GIS techniques. Arabian Journal of Geosciences 10(24); 552. https://doi.org/10.1007/s12517-017-3312-6

5. Bhattacharya RK, Chatterjee ND, Das K (2020) Sub-basin prioritization for assessment of soil erosion susceptibility in Kangsabati, a plateau basin: A comparison between MCDM and SWAT models. Science of The Total Environment, 734; 139474. https://doi.org/10.1016/j.scitotenv.2020.139747

6. Durbude DG, Purandara BK, Sharma A (2001) Estimation of surface runoff potential of a watershed in semi-arid environment-A case study. Journal of the Indian Society of Remote Sensing, 29(1); 47-58

7. Gajbhiye S, Mishra SK, Pandey A (2014) Prioritizing erosion-prone area through morphometric analysis. an RS and GIS perspective. Applied Water Science, 4(1); 5161. https://doi.org/10.1007/s13201-013-0129-7

8. Ganasri BP, Ramesh H (2016) Assessment of soil erosion by RUSLE model using remote sensing and GIS-A case study of Nethravathi Basin. Geoscience Frontiers, 7(6); 953961. http://dx.doi.org/10.1016/j.gsf.2015.10.007

9. Hembram TK, Saha S (2018) Prioritization of sub-watersheds for soil erosion based on morphometric attributes using fuzzy AHP and compound factor in Jainti River basin, Jharkhand, Eastern India. Environment, Development and Sustainability, 22(2); 12411268. https://doi.org/10.1007/s10668-018-0247-3

10. Jain MK, Kothyari UC (2000) Estimation of soil erosion and sediment yield using GIS. Hydrological Sciences Journal, 45(5); 771-786.

11. Javarayigowda NH, Basavaraju GKS, Jayaram SH (2018) Morphometric analysis of Karadya micro watershed: A case study of Mandya district. American Journal of Remote Sensing, 6(1); 15-22

12. Javed A, Khanday MY, Ahmed R (2009) Prioritization of sub-watersheds based on morphometric and land use analysis using Remote Sensing and GIS techniques, Journal of the Indian Society of Remote Sensing, 37(2); 261-274

13. Kadam AK, Jaweed TH, Kale SS, Umrikar BN, Sankhua RN (2019) Identification of erosion-prone areas using modified morphometric prioritization method and sediment production rate: A remote sensing and GIS approach. Geomatics, Natural Hazards and Risk, 10(1); 9861006. https://doi.org/10.1080/19475705.2018.1555189 
14. Kanth TA, Hassan Z (2010) Prioritization of watersheds in Wular catchment for sustainable development and management of natural resources. RecentResearch in Science and Technology, 2(4); $12-16$

15. Khawaja FA, Dirk HB (2008) Factors controlling specific sediment yield in the upper Indus river basin, northern Pakistan. Hydrological Process, (22); 3102-3114.

16. Malik A, Kumar A, Kandpal H (2019) Morphometric analysis and prioritization of sub-watersheds in a hilly watershed using weighted sum approach. Arabian Journal of Geosciences, 12(4); 118. https://doi.org/10.1007/s12517-019-4310-7

17. Meshram SG, Sharma SK (2015) Prioritization of watershed through morphometric parameters: a PCA-based approach. Applied Water Science, 7(3); 1505-1519. https://doi.org/10.1007/s13201-0150332-9

18. Nanda AM, Hamid A, Hassan Z, Ahmed P, Kanth TA (2015) Watershed prioritization using sediment yield index model for Vishav watershed of Jammu and Kashmir state (India). J. Himalayan Ecol. Sustian. Dev. (10); 87-94

19. Naqvi HR, Athick AMA, Ganaie HA, Siddiqui MA (2015) Soil erosion planning using sediment yield index method in the Nun Nadi watershed, India. International soil and water conservation research, 3(2); 86-96. http://dx.doi.org/10.1016/j.iswcr.2015.06.007

20. $\mathrm{NIH},(2000)$ Watershed prioritisation of Ukai dam catchment using Remote sensing and GIS. National Institute of Hydrology, Roorkee.

21. Pawar AD, Sarup J, Mittal SK (2014) Application of GIS and RS for Morphometric Analysis of Upper Bhima Basin: A Case Study. Journal of The Institution of Engineers (India): Series A, 95(4); 249257. https://doi.org/10.1007/s40030-014-0097-4

22. Rahmati O, Samadi M, Shahabi H, Azareh A, Rafiei-Sardooi E, Alilou H, Shirzadi A (2019) Swpt: An automated gis-based tool for prioritization of sub-watersheds based on morphometric and topohydrological factors. Geoscience Frontiers, 10(6); 2167-

2175. http://dx.doi.org/10.1016/j.gsf.2015.10.007

23. Ratnam KN, Srivastava YK, Rao VV, Amminedu E, Murthy KSR (2005) Check dam positioning by prioritization of micro-watersheds using SYI model and morphometric analysis remote sensing and GIS perspective. Journal of the Indian society of remote sensing, 33(1); 25-38

24. Sahoo S, Meher J (2019) Estimation of sub watershed wise morphometric parameters of Baitarani basin using Remote Sensing and Geoinformation System. In: Proceedings of the $24^{\text {th }}$ Hydro International Conference Hyderabad. India. 2559-2568.

25. Snehit B, Sahoo SN (2019) Prioritization of sub watersheds for soil conservation management using morphometric characteristics. In: Proceedings of the $24^{\text {th }}$ Hydro International Conference Hyderabad. India. 1399-1409.

26. Strahler AN (1957) Quantitative analysis of watershed geomorphology. Trans. Am Geophysics. Union 38(6); $913-920$ 
27. Subyani AM, Qari MH, Matsah MI (2012) Digital elevation model and multivariate statistical analysis of morphometric parameters of some wadis, western Saudi Arabia. Arabian Journal of Geosciences, 5(1); 147-157. https://doi.org/10.1007/s12517-010-0149-7

28. Yang X, Lu XX (2014) Estimate of cumulative sediment trapping by multiple reservoirs in large river basins: An example of the Yangtze river basin. Geomoprhology, (227); 49-

59. http://dx.doi.org/10.1016/j.geomorph.2014.01.014

29. Wagh S, Manekar V (2021) Assessment of reservoir sedimentation using satellite remote sensing technique (SRS), Journal of The Institution of Engineers (India): Series A, 102(3); 851-860. https://doi.org/10.1007/s40030-021-00539-8

\section{Tables}

Table 1 Estimation of morphometric parameters

(Source: Meshram et al. 2015; Kadam et al. 2019; Malik et al. 2019; Sahoo et al. 2019; Snehit et al. 2019; Arabameri et al. 2020; Bhattacharaya et al. 2020) 


\begin{tabular}{|c|c|c|c|}
\hline Sr.No & Aspect & $\begin{array}{l}\text { Morphometric } \\
\text { parameter }\end{array}$ & Estimation \\
\hline 1 & Basic & Basin area $(A)$ & Area enclosed within the watershed boundary $\left(\mathrm{Km}^{2}\right)$ \\
\hline 2 & & Basin perimeter $(P)$ & Perimeter of watershed $(\mathrm{Km})$ \\
\hline 3 & & Basin length $\left(L_{b}\right)$ & $\begin{array}{l}\text { Longest dimension of the basin parallel to the principal } \\
\text { drainage line }(\mathrm{Km})\end{array}$ \\
\hline 4 & & $\begin{array}{l}\text { Maximum height } \\
\left(H_{\text {max }}\right)\end{array}$ & Height of the lowest cell in the basin (m) \\
\hline 5 & & $\begin{array}{l}\text { Minimum height } \\
\left(H_{\min }\right)\end{array}$ & Height of the highest cell in the basin (m) \\
\hline 6 & & Mean height $\left(H_{\text {mean }}\right)$ & Arithmetic mean of the heights of all cells in the basin $(\mathrm{m})$ \\
\hline 7 & Linear & Stream order $(N)$ & Hierarchical order \\
\hline 8 & & Stream length $\left(L_{S}\right)$ & Length of stream $(\mathrm{Km})$ \\
\hline 9 & & $\begin{array}{l}\text { Number of streams } \\
\left(N_{S}\right)\end{array}$ & Total number streams of all order \\
\hline 10 & & Bifurcation ratio $\left(R_{b}\right)$ & $\begin{array}{l}R_{b}=\left(N_{\mathrm{s}} / N_{s}+1\right) \\
\text { Where, } N_{s} \text { and } N_{s}+1 \text { are total number of stream segments of } \\
\text { order } \mathrm{u} \text { and stream segments of next higher order }\end{array}$ \\
\hline 11 & & $\begin{array}{l}\text { Mean bifurcation } \\
\text { ratio }\left(R_{b m}\right)\end{array}$ & Average of bifurcation ratio of all orders \\
\hline 12 & Areal & $\begin{array}{l}\text { Drainage density } \\
\left(D_{d}\right)\end{array}$ & $\begin{array}{l}D_{d}=\left(L_{s} / A\right) \text { expressed in }\left(\mathrm{Km}^{-1}\right) \\
\text { Where } L_{\mathrm{s}} \text { is the total steam length of all orders }(\mathrm{Km})\end{array}$ \\
\hline 13 & & $\begin{array}{l}\text { Stream frequency } \\
\left(F_{S}\right)\end{array}$ & $F_{S}=\left(N_{s} / A\right)$ expressed in $\left(\mathrm{Km}^{-2}\right)$ \\
\hline 14 & & Texture ratio $\left(R_{t}\right)$ & $R_{t}=\left(N_{s} / P\right)$ expressed in $\left(\mathrm{Km}^{-1}\right)$ \\
\hline 15 & & $\begin{array}{l}\text { Length of overland } \\
\text { flow }\left(L_{o f}\right)\end{array}$ & $L_{o f}=1 /\left(2 \times D_{d}\right)$ expressed in $(\mathrm{Km})$ \\
\hline 16 & & $\begin{array}{l}\text { Constant of channel } \\
\text { maintenance }\left(C_{c m}\right)\end{array}$ & $C_{C m}=\left(1 / D_{d}\right)$ expressed in $(\mathrm{Km})$ \\
\hline 17 & Shape & Form factor $\left(F_{f}\right)$ & $F_{f}=\left(A / L b^{\wedge} 2\right)$ \\
\hline 18 & & Elongation ratio $\left(R_{e}\right)$ & $R_{e}=$ \\
\hline 19 & & $\begin{array}{l}\text { Compactness } \\
\text { coefficient }\left(C_{C}\right)\end{array}$ & $C_{C}=0.2821 \mathrm{x}$ \\
\hline 20 & & Circulatory ratio $\left(R_{C}\right)$ & $R_{C}=4 \pi \mathrm{x}$ \\
\hline 21 & Landscape & Basin relief $(R)$ & $\begin{array}{l}R=\left(H_{\max }-H_{\min }\right) \text { expressed in }(\mathrm{m}) \\
\text { Where } H_{\max }=\text { Maximum height in }(\mathrm{m}) \\
H_{\min }=\text { Minimum height in }(\mathrm{m})\end{array}$ \\
\hline 22 & & $\begin{array}{l}\text { Ruggedness number } \\
\left(R_{N}\right)\end{array}$ & $R_{N}=D_{d} \times(R / 1000)$ \\
\hline
\end{tabular}




\begin{tabular}{|c|c|c|}
\hline 23 & Relief ratio $\left(R_{r}\right)$ & $R_{r}=R / L_{b}$ \\
\hline 24 & Relative relief $\left(R_{r f}\right)$ & $R_{r f}=R / P$ \\
\hline 25 & $\begin{array}{l}\text { Relief peakedness } \\
\left(R_{p k}\right)\end{array}$ & $R_{p \mathrm{k}}=\left(H_{\text {mean }}\right) /\left(H_{\max }\right)$ \\
\hline 26 & $\begin{array}{l}\text { Hypsometric integral } \\
\left(H_{I}\right)\end{array}$ & $H_{I}=\left(H_{\text {mean }}-H_{\min }\right) /\left(H_{\max }-H_{\min }\right)$ \\
\hline 27 & Slope $(G)$ & $G=H_{\text {mean }} /$ \\
\hline 28 & $\begin{array}{l}\text { Ruggedness index } \\
\left(R_{G}\right)\end{array}$ & $R_{G}=R \times(A)^{-0.5}$ \\
\hline
\end{tabular}

Table 2 Basic parameters of Bhima basin

\begin{tabular}{|c|c|c|c|c|c|c|}
\hline \multirow{2}{*}{ Watershed name } & \multicolumn{6}{|c|}{ Basic morphometric parameters } \\
\hline & $A\left(\mathrm{Km}^{2}\right)$ & $P(\mathrm{Km})$ & $L_{b}(\mathrm{Km})$ & $H_{\max }(\mathrm{m})$ & $H_{\min }(\mathrm{m})$ & $H_{\text {mean }}(\mathrm{m})$ \\
\hline 4D7F1 & 707 & 182 & 79 & 605 & 476 & 531 \\
\hline 4D7F2 & 595 & 138 & 68 & 660 & 497 & 544 \\
\hline 4D7F3 & 725 & 148 & 47 & 610 & 477 & 531 \\
\hline 4D7F4 & 911 & 155 & 54 & 700 & 479 & 551 \\
\hline 4D7F5 & 732 & 148 & 46 & 789 & 498 & 567 \\
\hline 4D7G1 & 614 & 108 & 31 & 678 & 518 & 550 \\
\hline 4D7G2 & 884 & 143 & 70 & 867 & 517 & 571 \\
\hline 4D7G3 & 729 & 147 & 52 & 1054 & 560 & 739 \\
\hline 4D7G4 & 1341 & 175 & 70 & 1076 & 550 & 663 \\
\hline 4D7G5 & 1080 & 199 & 99 & 960 & 522 & 624 \\
\hline 4D7G6 & 672 & 148 & 77 & 1023 & 576 & 738 \\
\hline 4D7G7 & 1473 & 213 & 108 & 1053 & 525 & 667 \\
\hline 4D7H1 & 990 & 205 & 50 & 894 & 520 & 634 \\
\hline 4D7H2 & 500 & 112 & 39 & 804 & 538 & 598 \\
\hline 4D7H3 & 439 & 113 & 50 & 806 & 563 & 626 \\
\hline 4D7H4 & 713 & 153 & 62 & 1109 & 617 & 798 \\
\hline 4D7H5 & 384 & 137 & 61 & 1100 & 600 & 733 \\
\hline 4D7H6 & 808 & 148 & 63 & 943 & 562 & 668 \\
\hline 4D7H7 & 538 & 121 & 50 & 1184 & 637 & 737 \\
\hline
\end{tabular}


Table 3 Linear morphometric parameters of Bhima basin

\begin{tabular}{|c|c|c|c|c|c|c|c|c|}
\hline \multirow{2}{*}{$\begin{array}{l}\text { Watershed } \\
\text { name }\end{array}$} & \multirow{2}{*}{ Parameters } & \multicolumn{6}{|c|}{ Stream order } & \multirow{2}{*}{ Total } \\
\hline & & I & II & III & IV & $\mathrm{V}$ & VI & \\
\hline \multirow[t]{2}{*}{ 4D7Fl } & $\begin{array}{l}\text { No. of streams }\left(N_{s}\right) \\
\text { Stream length }\left(L_{s}\right) \text { in Km }\end{array}$ & $\begin{array}{l}864 \\
355\end{array}$ & $\begin{array}{l}395 \\
197\end{array}$ & $\begin{array}{l}136 \\
79\end{array}$ & $\begin{array}{l}257 \\
40\end{array}$ & $\begin{array}{l}0 \\
0\end{array}$ & $\begin{array}{l}0 \\
0\end{array}$ & $\begin{array}{l}1652 \\
671\end{array}$ \\
\hline & Bifurcation ratio $\left(R_{b}\right)$ & 2.19 & 2.90 & 0.53 & - & - & - & 5.62 \\
\hline \multirow{3}{*}{ 4D7F2 } & No. of streams $\left(N_{s}\right)$ & 803 & 330 & 125 & 70 & 41 & 0 & 1369 \\
\hline & Stream length $\left(L_{x}\right)$ in $\mathrm{Km}$ & 302 & 173 & 59 & 23 & 18 & 0 & 575 \\
\hline & Bifurcation ratio $\left(R_{b}\right)$ & 2.43 & 2.64 & 1.79 & 1.71 & - & - & 8.57 \\
\hline \multirow[t]{3}{*}{ 4D7F3 } & No. of streams $\left(N_{s}\right)$ & 856 & 298 & 220 & 149 & 0 & 0 & 1523 \\
\hline & Stream length $\left(L_{-}\right)$in $\mathrm{Km}$ & 376 & 165 & 100 & 41 & 0 & 0 & 683 \\
\hline & Bifurcation ratio $\left(R_{b}\right)$ & 2.87 & 1.35 & 1.48 & - & - & - & 5.70 \\
\hline \multirow[t]{3}{*}{ 4D7F4 } & No. of streams $\left(N_{s}\right)$ & 830 & 320 & 231 & 97 & 114 & 0 & 1592 \\
\hline & Stream length $\left(L_{s}\right)$ in $\mathrm{Km}$ & 481 & 203 & 123 & 54 & 27 & 0 & 888 \\
\hline & Bifurcation ratio $\left(R_{b}\right)$ & 2.59 & 1.39 & 2.38 & 0.85 & - & - & 7.21 \\
\hline \multirow[t]{3}{*}{ 4D7F5 } & No. of streams $\left(N_{s}\right)$ & 954 & 432 & 212 & 153 & 28 & 0 & 1779 \\
\hline & Stream length $\left(L_{s}\right)$ in $\mathrm{Km}$ & 397 & 206 & 87 & 70 & 10 & 0 & 769 \\
\hline & Bifurcation ratio $\left(R_{b}\right)$ & 2.21 & 2.04 & 1.39 & 5.46 & - & - & 11.10 \\
\hline \multirow{3}{*}{ 4D7Gl } & No. of streams $\left(N_{s}\right)$ & 744 & 350 & 207 & 136 & 93 & 0 & 1530 \\
\hline & Stream length $\left(L_{x}\right)$ in $\mathrm{Km}$ & 339 & 182 & 106 & 44 & 21 & 0 & 692 \\
\hline & Bifurcation ratio $\left(R_{b}\right)$ & 2.13 & 1.69 & 1.52 & 1.46 & - & - & 6.80 \\
\hline \multirow[t]{3}{*}{ 4D7G2 } & No. of streams $\left(N_{s}\right)$ & 934 & 415 & 270 & 171 & 196 & 0 & 1986 \\
\hline & Stream length $\left(L_{0}\right)$ in $\mathrm{Km}$ & 521 & 279 & 154 & 35 & 63 & 0 & 1051 \\
\hline & Bifurcation ratio $\left(R_{b}\right)$ & 2.25 & 1.54 & 1.58 & 0.87 & - & - & 6.24 \\
\hline \multirow[t]{3}{*}{ 4D7G3 } & No. of streams $\left(N_{s}\right)$ & 846 & 381 & 223 & 152 & 120 & 0 & 1722 \\
\hline & Stream length $\left(L_{3}\right)$ in $\mathrm{Km}$ & 381 & 213 & 70 & 49 & 30 & 0 & 748 \\
\hline & Bifurcation ratio $\left(R_{b}\right)$ & 2.22 & 1.71 & 1.47 & 1.27 & - & - & 6.66 \\
\hline \multirow[t]{3}{*}{ 4D7G4 } & No. of streams $\left(N_{s}\right)$ & 2319 & 1162 & 608 & 417 & 296 & 0 & 4802 \\
\hline & Stream length $\left(L_{3}\right)$ in $\mathrm{Km}$ & 757 & 356 & 152 & 102 & 59 & 0 & 1430 \\
\hline & Bifurcation ratio $\left(R_{b}\right)$ & 2.00 & 1.91 & 1.46 & 1.41 & - & - & 6.77 \\
\hline \multirow{3}{*}{ 4D7G5 } & No. of streams $\left(N_{\mathrm{s}}\right)$ & 1080 & 533 & 242 & 186 & 179 & 41 & 2261 \\
\hline & Stream length $\left(L_{3}\right)$ in $\mathrm{Km}$ & 535 & 298 & 151 & 74 & 56 & 21 & 1136 \\
\hline & Bifurcation ratio $\left(R_{b}\right)$ & 2.03 & 2.20 & 1.30 & 1.04 & 4.37 & - & 10.93 \\
\hline \multirow[t]{3}{*}{ 4D7G6 } & No. of streams $\left(N_{s}\right)$ & 664 & 371 & 178 & 112 & 142 & 0 & 1467 \\
\hline & Stream length $\left(L_{x}\right)$ in $\mathrm{Km}$ & 336 & 197 & 84 & 33 & 44 & 0 & 694 \\
\hline & Bifurcation ratio $\left(R_{b}\right)$ & 1.79 & 2.08 & 1.59 & 0.79 & - & - & 6.25 \\
\hline \multirow[t]{3}{*}{ 4D7G7 } & No. of streams $\left(N_{s}\right)$ & 1950 & 880 & 398 & 394 & 193 & 263 & 4078 \\
\hline & Stream length $\left(L_{3}\right)$ in $\mathrm{Km}$ & 839 & 381 & 167 & 84 & 59 & 69 & 1598 \\
\hline & Bifurcation ratio $\left(R_{b}\right)$ & 2.22 & 2.21 & 1.01 & 2.04 & 0.73 & - & 8.21 \\
\hline 4D7Hl & No. of streams $\left(N_{s}\right)$ & 954 & 461 & 230 & 104 & 244 & 0 & 1993 \\
\hline & Stream length $\left(L_{x}\right)$ in $\mathrm{Km}$ & 506 & 266 & 112 & 57 & 70 & 0 & 1012 \\
\hline & Bifurcation ratio $\left(R_{b}\right)$ & 2.07 & 2.00 & 2.21 & 0.43 & - & - & 6.71 \\
\hline 4D7H2 & No. of streams $\left(N_{s}\right)$ & 492 & 217 & 94 & 31 & 48 & 0 & 882 \\
\hline & Stream length $\left(L_{x}\right)$ in $\mathrm{Km}$ & 302 & 173 & 59 & 23 & 18 & 0 & 575 \\
\hline & Bifurcation ratio $\left(R_{b}\right)$ & 2.27 & 2.31 & 3.03 & 0.65 & - & - & 8.25 \\
\hline 4D7H3 & No. of streams $\left(N_{s}\right)$ & 502 & 228 & 97 & 110 & 68 & 0 & 1005 \\
\hline & Stream length $\left(L_{s}\right)$ in $\mathrm{Km}$ & 251 & 141 & 46 & 26 & 22 & 0 & 486 \\
\hline & Bifurcation ratio $\left(R_{b}\right)$ & 2.20 & 2.35 & 0.88 & 1.62 & - & - & 7.05 \\
\hline 4D7H4 & No. of streams $\left(N_{s}\right)$ & 832 & 498 & 215 & 39 & 249 & 0 & 1833 \\
\hline & Stream length $\left(L_{x}\right)$ in $\mathrm{Km}$ & 383 & 196 & 103 & 24 & 49 & 0 & 754 \\
\hline & Bifurcation ratio $\left(R_{b}\right)$ & 1.67 & 2.32 & 5.51 & 0.16 & - & - & 9.66 \\
\hline 4D7H5 & No. of streams $\left(N_{s}\right)$ & 444 & 144 & 146 & 164 & 0 & 0 & 898 \\
\hline & Stream length $\left(L_{x}\right)$ in $\mathrm{Km}$ & 224 & 90 & 39 & 43 & 0 & 0 & 396 \\
\hline & Bifurcation ratio $\left(R_{b}\right)$ & 3.08 & 0.99 & 0.89 & - & - & - & 4.96 \\
\hline 4D7H6 & No. of streams $\left(N_{s}\right)$ & 746 & 359 & 182 & 79 & 152 & 0 & 1518 \\
\hline & Stream length $\left(L_{x}\right)$ in $\mathrm{Km}$ & 473 & 280 & 113 & 55 & 50 & 0 & 971 \\
\hline & Bifurcation ratio $\left(R_{b}\right)$ & 2.08 & 1.97 & 2.30 & 0.52 & - & - & 6.87 \\
\hline 4D7H7 & No. of streams $\left(N_{s}\right)$ & 603 & 279 & 141 & 234 & 74 & 0 & 1331 \\
\hline & Stream length $\left(L_{s}\right)$ in $\mathrm{Km}$ & 326 & 143 & 60 & 66 & 7 & 0 & 602 \\
\hline & Bifurcation ratio $\left(R_{b}\right)$ & 2.16 & 1.98 & 0.60 & 3.16 & - & - & 7.90 \\
\hline
\end{tabular}




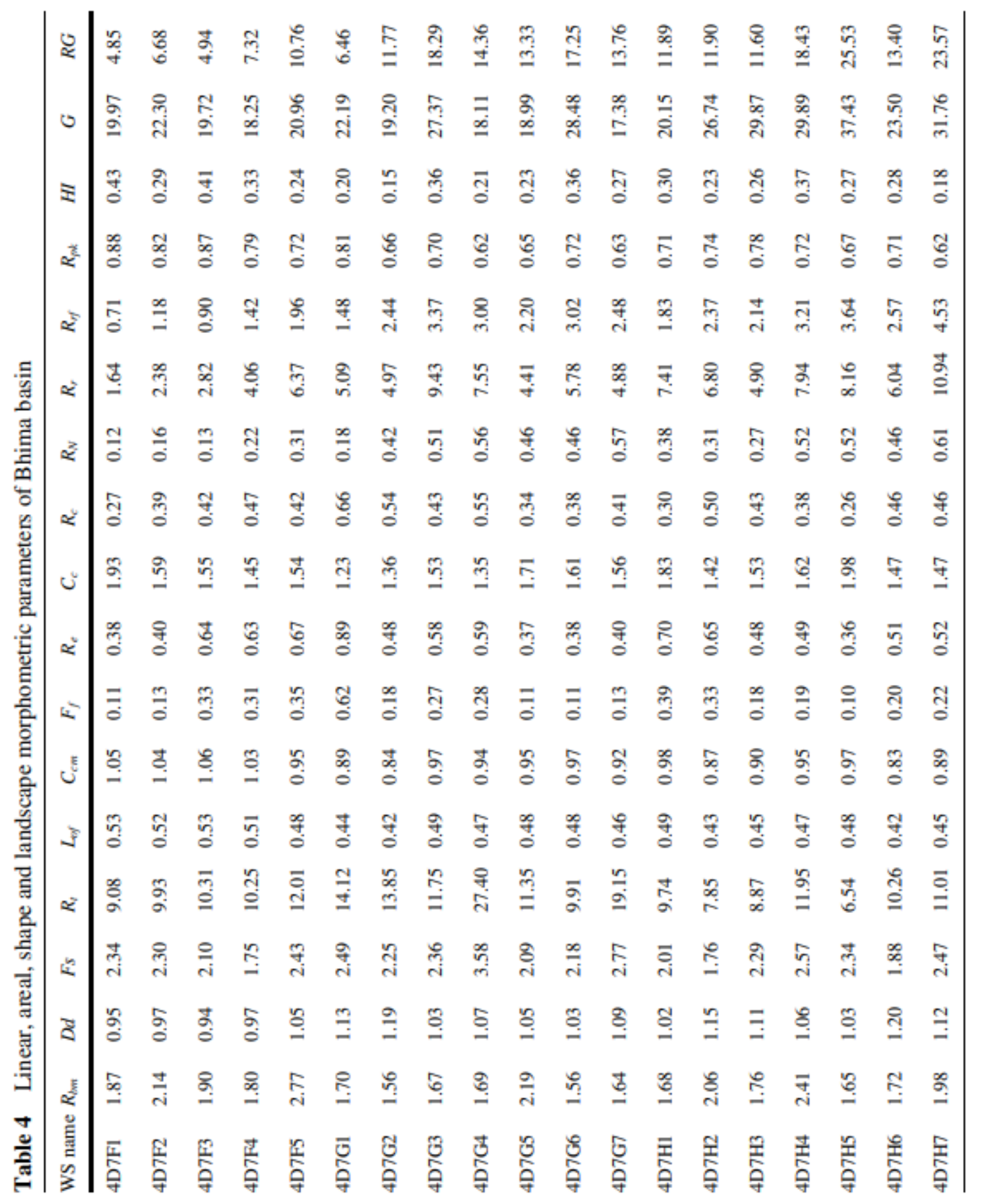




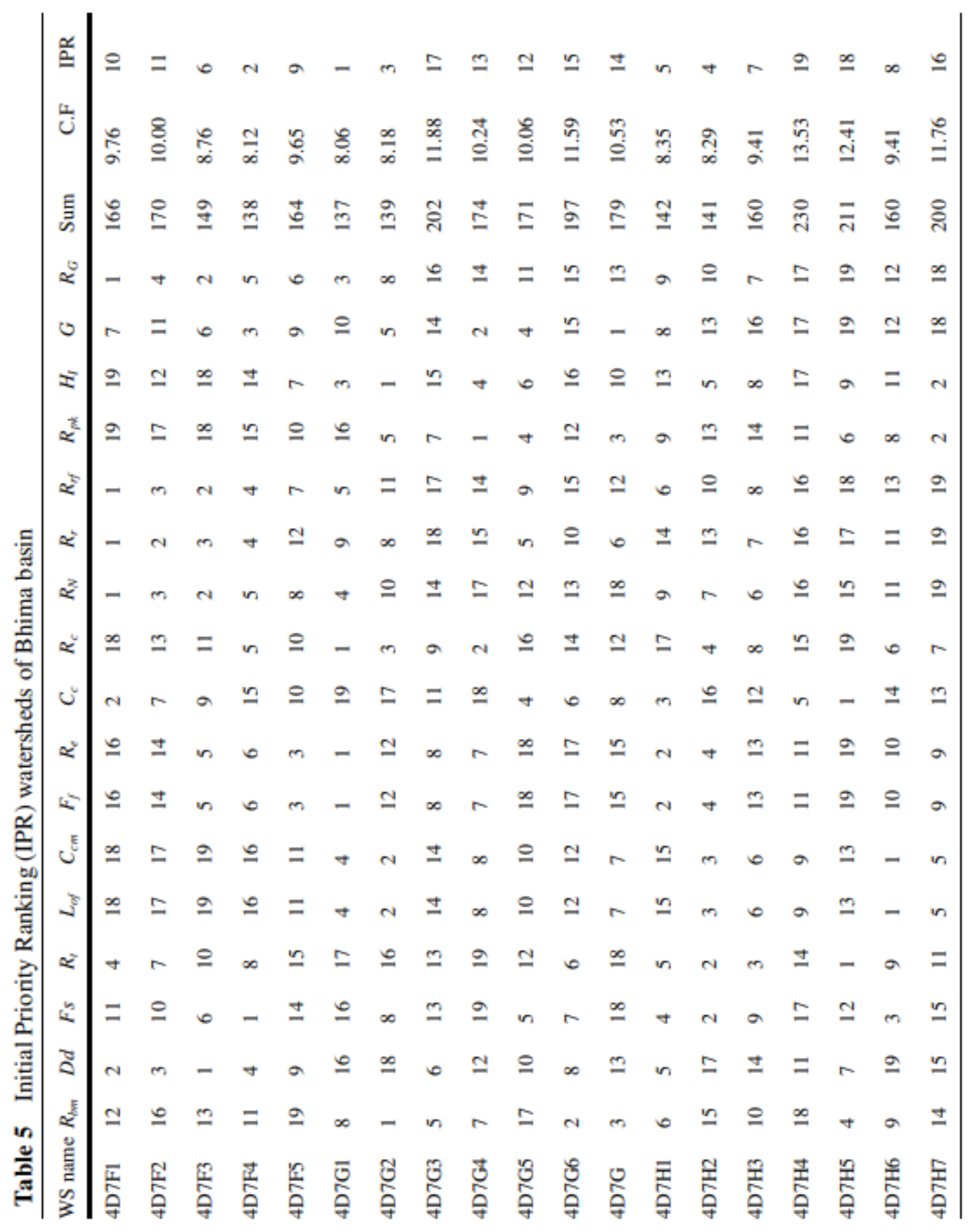




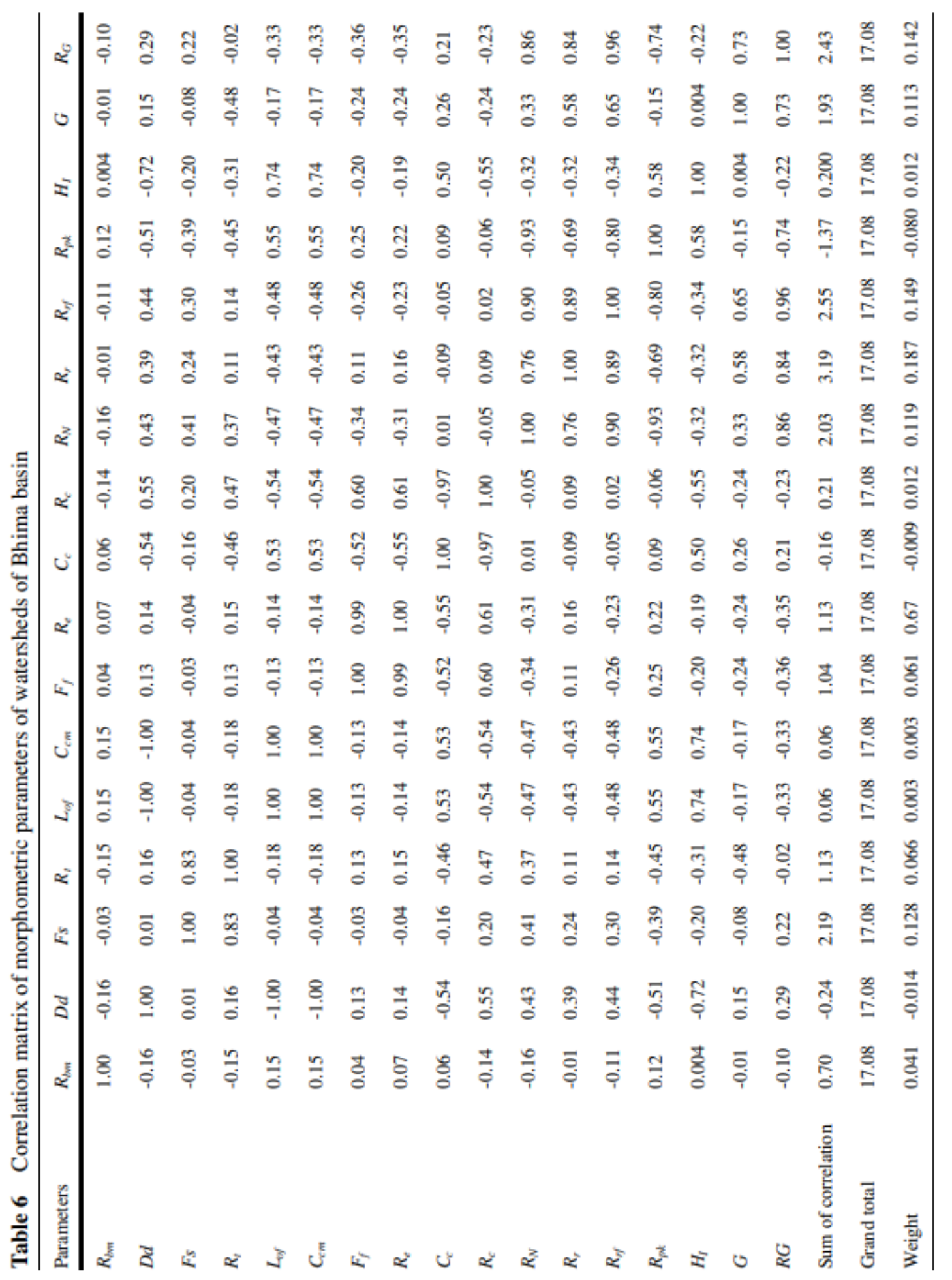




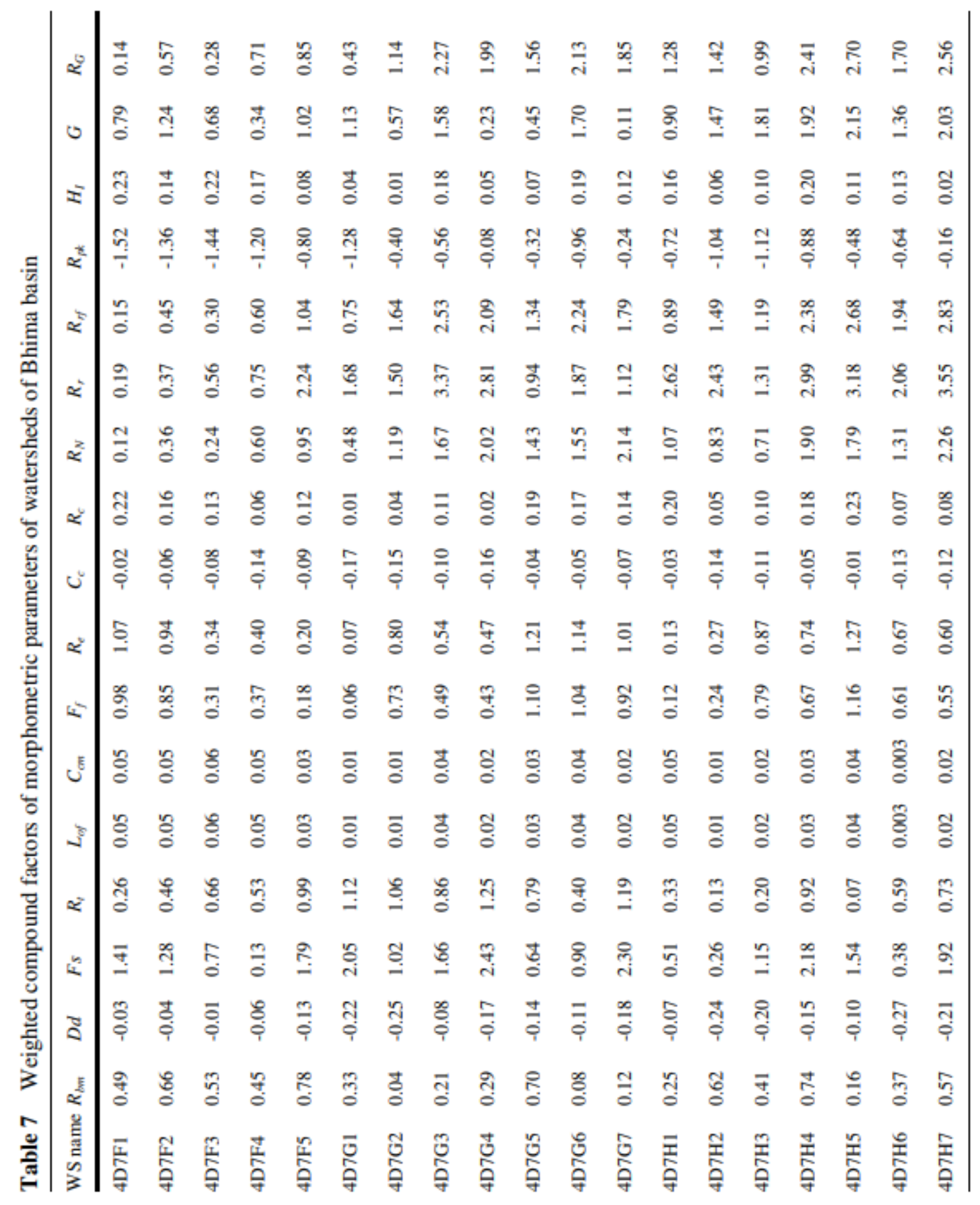

Table 8 Final priority ranking of 19 watersheds based on weighted compound factor value 


\begin{tabular}{lll}
\hline Watershed name & Weighted compound factor & Final priority rank \\
\hline 4D7F1 & 4.59 & 3 \\
4D7F2 & 6.12 & 4 \\
\hline 4D7F3 & 3.59 & 1 \\
\hline 4D7F4 & 3.80 & 2 \\
\hline 4D7F5 & 9.31 & 10 \\
\hline 4D7G1 & 6.48 & 5 \\
\hline 4D7G2 & 8.94 & 9 \\
\hline 4D7G3 & 14.80 & 16 \\
\hline 4D7G4 & 13.71 & 15 \\
\hline 4D7G5 & 9.98 & 11 \\
\hline 4D7G6 & 12.33 & 13 \\
\hline 4D7G7 & 12.36 & 14 \\
\hline 4D7H1 & 7.74 & 6 \\
\hline 4D7H2 & 7.86 & 7 \\
\hline 4D7H3 & 8.25 & 8 \\
\hline 4D7H4 & 16.22 & 17 \\
\hline 4D7H5 & 16.52 & 18 \\
\hline 4D7H6 & 10.17 & 12 \\
\hline 4D7H7 & 17.26 & 19 \\
\hline
\end{tabular}

Table 9 Priority category of 19 watersheds in the Bhima basin

\begin{tabular}{lllll}
\hline Sr. No. & Priority level & Category & \multicolumn{1}{c}{ Watershed name } & Percentage area \\
\hline 1 & 4.59 to 7.12 & Very low & 4D7F1, 4D7F2, 4D7F3,4D7F4 and 4D7G1 & 23.93 \\
2 & 7.12 to 9.65 & Low & 4D7F5,4D7G2, 4D7H1, 4D7H2 and 4D7H3 & 23.90 \\
\hline 3 & 9.65 to 12.19 & Medium & 4D7G5 and 4D7H6 & 12.73 \\
\hline 4 & 12.19 to 14.72 & High & 4D7G4, 4D7G6 and 4D7G7 & 23.50 \\
\hline 5 & 14.72 to 17.26 & Very high & 4D7G3, 4D7H4, 4D7H5 and 4D7H7 & 15.94 \\
\hline
\end{tabular}

\section{Figures}




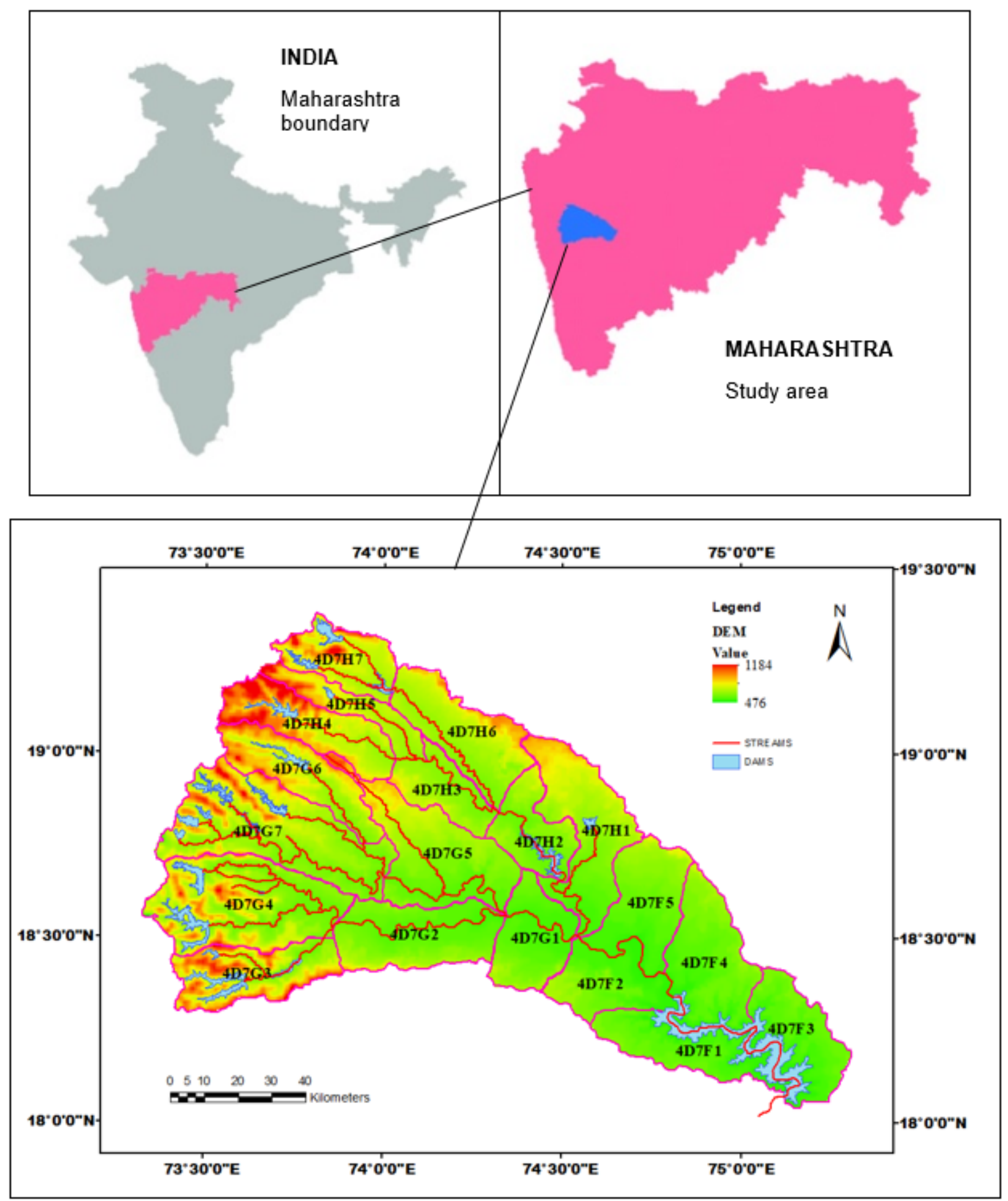

Figure 1

Location map of the study area 


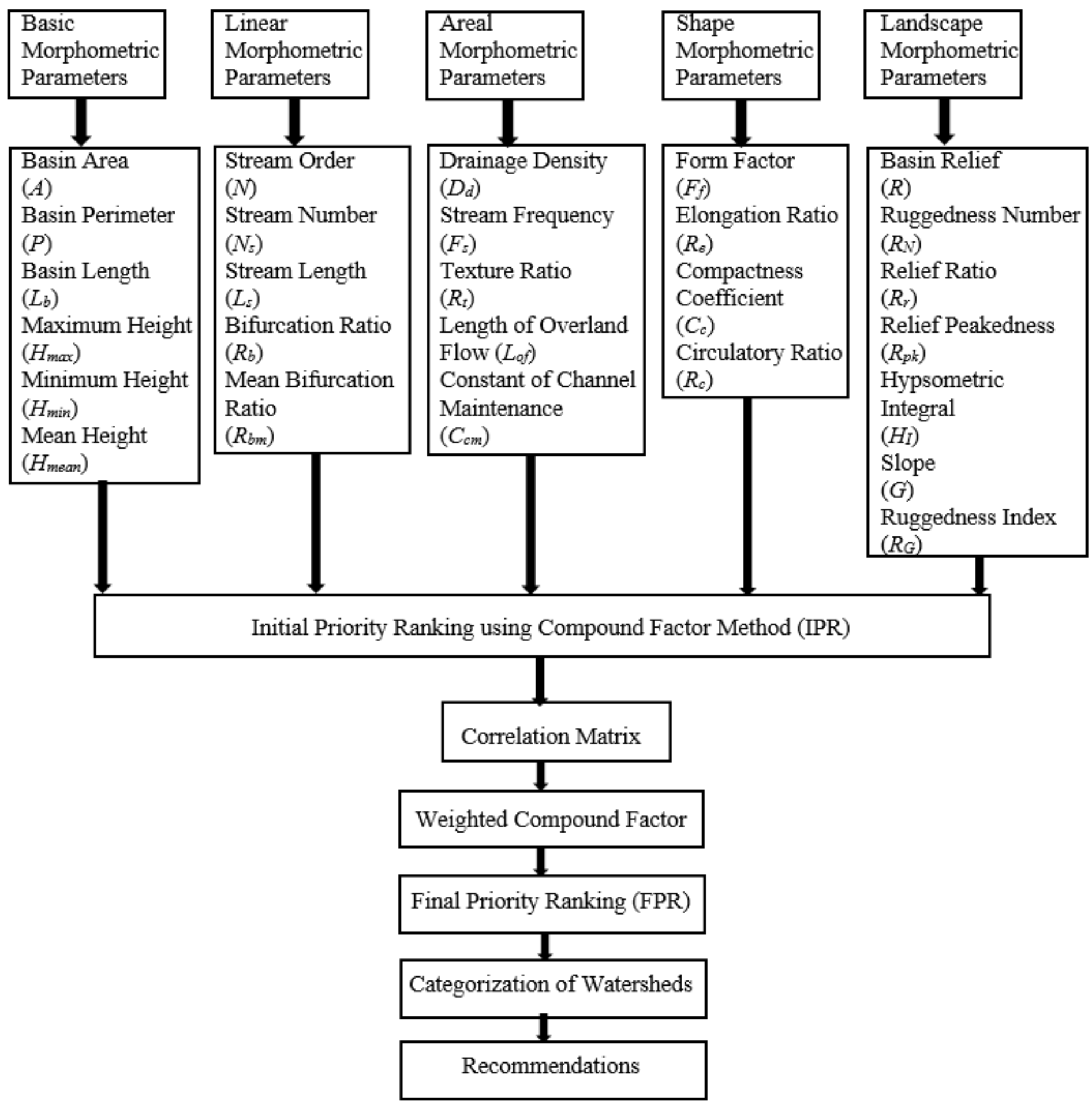

Figure 2

Flow chart of methodology adopted for watershed prioritization and categorization 


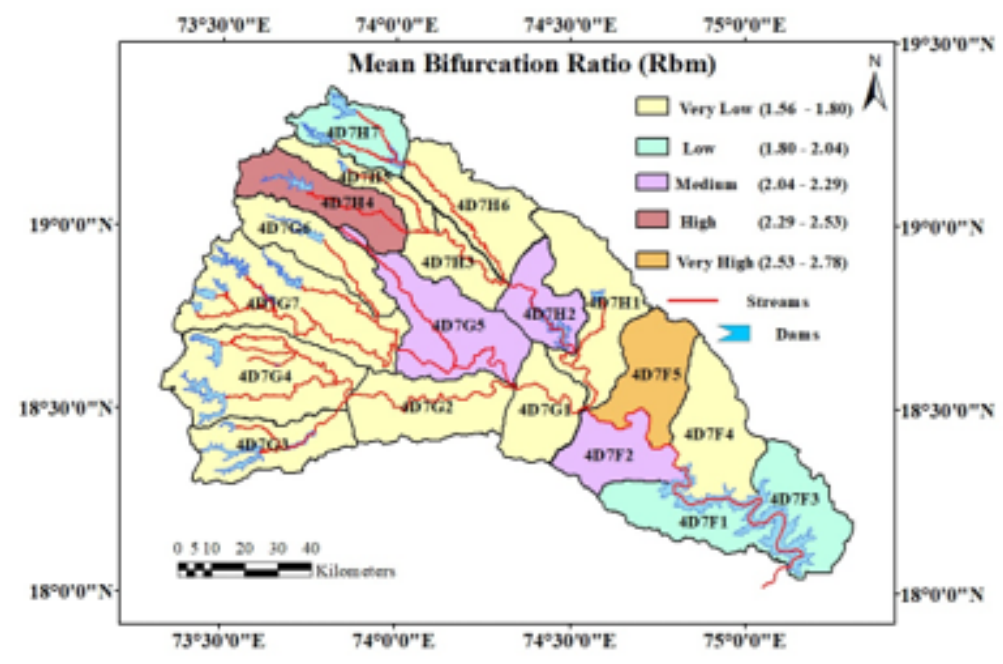

Figure 3

Mean bifurcation ratio of Bhima basin 



\section{Figure 4}

Areal parameters of the study area: a. drainage density, b. stream frequency, c. texture ratio, d. length of overland, e. constant of channel maintenance 



\section{Figure 5}

Shape parameters of the study area: $a$. form factor, b. elongation ratio, c. compactness coefficient, $d$. circulatory ratio 

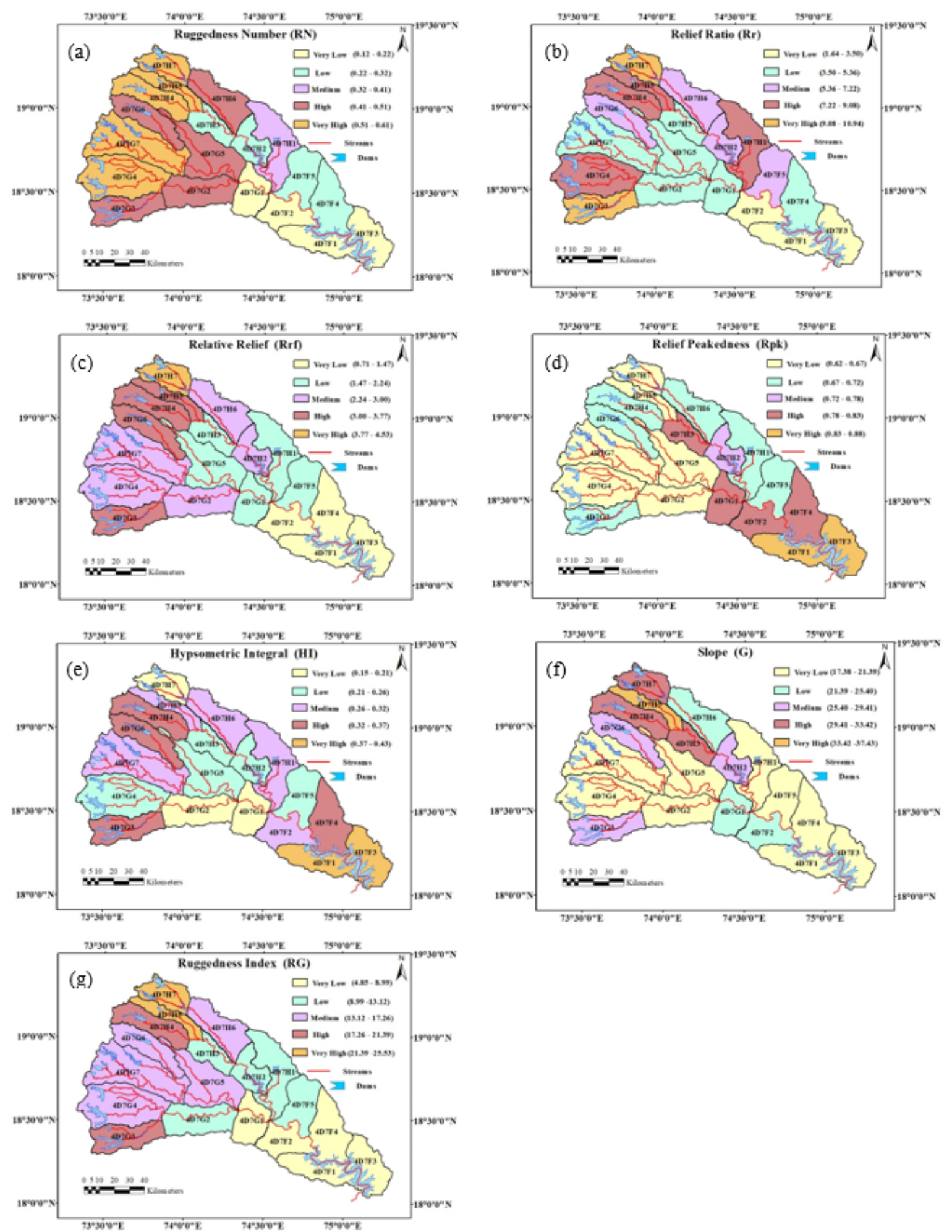

\section{Figure 6}

Landscape parameters of the study area: a. ruggedness number, b. relief ratio, c. relative relief, d. relief peakedness, e. hypsometric integral, f. slope, g. ruggedness index 


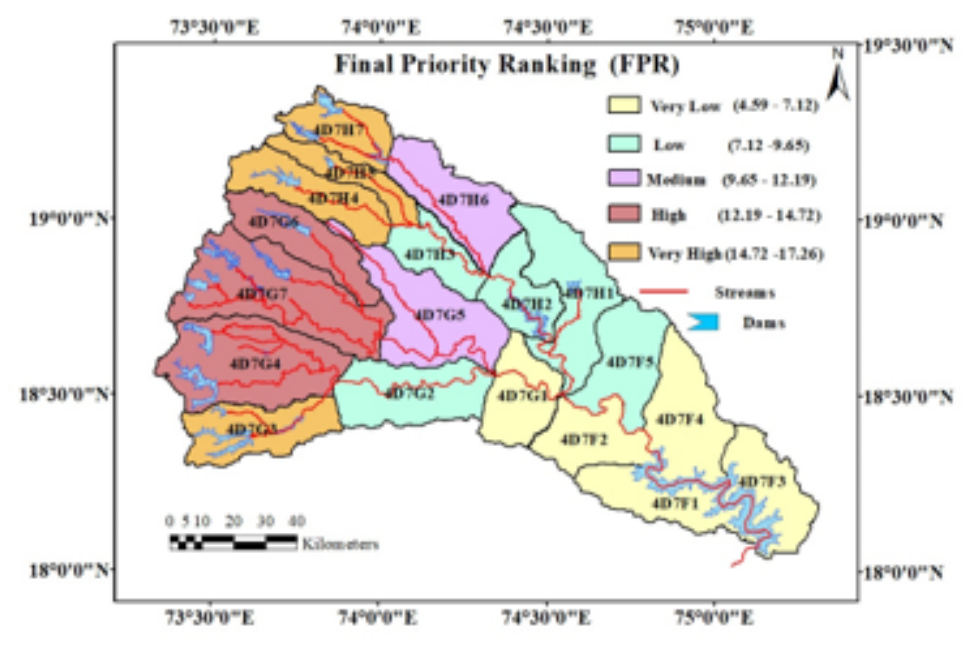

Figure 7

Final priority category of 19 watersheds of Bhima basin 